\title{
Influence of tannic acid on milk lipid composition of cows
}

\author{
Ana Jaqueline Cavalcante MUNIZ1 ${ }^{1}$, Severino GONZAGA NETO ${ }^{1}$, Lara Toledo HENRIQUES², \\ Roberto Germano COSTA ${ }^{1}$, Rita de Cássia Ramos do Egypto QUEIROGA³, Carla Aparecida Soares SARAIVA ${ }^{1}$, \\ Carla Giselly de SOUZA ${ }^{1}$, Neila Lidiany RIBEIRO ${ }^{1 *}$
}

\begin{abstract}
The study aimed to evaluate tannic acid's influence on lactating cows' diets on milk production and lipid composition. Five crossbred cows (Holstein $\mathrm{x}$ Zebu), distributed in a $5 \times 5$ Latin square, were used to evaluate the effect of increasing tannic acid (hydrolyzable tannin). The diets were composed of $35 \mathrm{~kg}$ of corn silage as bulking and $6.38 \mathrm{~kg}$ of concentrate. The treatments consisted of increasing levels of tannic acid added to diets $(0 \%, 1.3 \%, 2.6 \%, 3.9 \%$ and $5.2 \%)$. It was observed a decreasing linear effect $(\mathrm{P}<0.05)$ of the inclusion of tannic acid in the concentration of saturated butyric fatty acids $(\mathrm{C} 4: 0)$ presenting a mean of (2.99), and quadratic effect in the concentration of saturated fatty acids lauric (C12:0) presenting mean (26.74). The addition of tannic acid had effects on saturated fatty acids, decreasing the concentrations of butyric acid and increasing the concentrations of lauric acid. Atherogenicity and thrombogenicity rates reveal the potential for the prevention of coronary heart disease. However, the observed changes do not compromise the milk's chemical composition and nutritional quality,the y nutritional quality of the milk, presenting possibilities of human health benefits, thus enabling the aggregation of value for these products.
\end{abstract}

Keywords: atherogenicity; fatty acids; nutritional quality; tannin.

Practical Application: Animal nutrition plays a fundamental role in the milk production system because in addition to being a determining tool for production, it influences the quality and is associated with a considerable share of the dairy herd

\section{Introduction}

Milk is one of the foods with a crucial nutritional composition for human health. Among the components of milk, fat has been associated with human diseases for years due to its high saturated fatty acid contente (Palmquist, 2010). About $70 \%$ of the fatty acids in milk triacylglycerols are saturated, $25 \%$ are monounsaturated fatty acids (MUFA), and 5\% are polyunsaturated fatty acids (PUFA) (Lopes et al., 2016; Abd El-Salam \& El-Shibiny, 2020). Studies have shown nutritional components of milk fat, with an emphasis on conjugated linoleic acid (CLA), which consists of a group of fatty acids found predominantly in the milk (Agiral et al., 2020) and meat of ruminant animals, such as cows' (Ruiz et al., 2016), sheep (Nudda et al., 2014, Madruga et al., 2020), and goat (Apás et al., 2015). In milk, fatty acids can come from the diet, transported to the mammary gland or synthesized by the mammary epithelial cells (Vargas-Bello-Perez et al., 2020).

Animal nutrition plays a fundamental role in the milk production system because in addition to being a determining tool for production, it influences the quality and is associated with a considerable share of the dairy herd (Lopes et al., 2011; Agiral et al., 2020). Some substances that modify milk's sensory characteristics are likely to result from intense changes in food compounds during digestion and intermediate metabolism from microbial and enzymatic processes (Addis et al., 2006).
Phenolic compounds make a positive contribution to taste at a considerable concentration but tend to be unpleasant as their concentration increases (Urbach, 2006).

Consequently, tannins in the feeding of ruminants can alter the food's characteristics by interfering with the ruminal biohydrogenation process, allowing changes in the volatile fraction of milk (Delacroix-Buchet \& Lamberet, 2000). Tannins were initially considered anti-nutritional biochemicals due to their adverse effects on voluntary consumption and nutrient use (Monteiro et al., 2005). Tannins are known as beneficial phytochemicals, improving ruminal metabolism, decreasing methanogenesis and protein degradation in the rumen, optimizing the production of microbial protein and increasing the flow of protein to the duodenum, targeting groups of specific microbial populations (Goel et al., 2005). Tannins can interfere with ruminal biohydrogenation and to favorably modify the dietary biohydrogenation of PUFAs, in addition to increasing the accumulation of 18: 1 trans-11 acid, due to an inhibition of the last step of biohydrogenation, and also act in the enrichment of acids conjugated linoleic agents (CLAs) in milk and act to inhibit methane emission (Carreño et al., 2015).

The present work hypothesizes that the diet added with tannic acid contribute to better composition of fatty acids in 
Table 1. Chemical composition of the ingredients of the experimental diets (\%).

\begin{tabular}{lccccccc}
\hline \multicolumn{1}{c}{ Ingredient } & DM & CP & EE & NDF & MM & NFC & TC \\
\hline Silage & 28.19 & 7.96 & 2.20 & 55.08 & 4.77 & 33.62 & 84.79 \\
Ground corn & 86.68 & 8.97 & 4.27 & 13.98 & 1.17 & 74.47 & 80.61 \\
Sorghum A9904 & 85.85 & 9.28 & 2.80 & 14.03 & 3.49 & 73.90 & 82.41 \\
Sorghum control & 79.61 & 9.34 & 2.80 & 14.03 & 3.49 & 73.90 & 82.41 \\
Wheat bran & 87.73 & 16.40 & 1.70 & 44.50 & 6.26 & 30.05 & 73.99 \\
Soybean meal & 88.30 & 48.78 & 1.97 & 14.46 & 6.13 & 30.40 & 43.45 \\
Urea & 100 & 283 & 0.00 & 0.00 & 0.00 & 0.00 & 0.00 \\
Mineral mix & 100 & 0.00 & 0.00 & 0.00 & 100 & 0.00 & 0.00 \\
\hline
\end{tabular}

Dry Matter $=$ DM, Crude Protein $=$ CP, Ethereal Extract $=$ EE, Neutral Detergent Fiber $=$ NDF, Matéria Mineral $(M M)$, Non-Fibrous Carbohydrates $=$ NFC, Total Carbohydrates $=$ TC.

milk. Thus, ths study aimed to evaluate the addition of tannic acid to the diet of lactating cows and its effect on milk production and lipid composition.

\section{Material and methods}

\subsection{Animals}

This research was approved by the Animal Use Ethics Committee (CEUA) of the Federal University of Paraíba (protocol No. 072/2016). The five primiparous crossbred cows (Holstein $\mathrm{x}$ Zebu) were used, with about four years old, the average body weight of $420 \pm 30 \mathrm{~kg}, 100$ days of lactation initial average production of $18 \pm 4 \mathrm{~kg}$ of milk / cow /day. Before starting the experiment, the cows were dewormed and treated against ectoparasites with 3.5\% Ivermectin. The animals were housed in individual stalls with $12 \mathrm{~m}^{2}$ fully covered with clay tiles, covered by concrete floor (lined with sugarcane bagasse). All stalls had a masonry feeder and plastic waterer.

The experiment lasted 100 days, divided into 05 periods of 20 days each, with 15 days for adaptation of the animals to the diets and the last 05 days to collect data and samples.

\subsection{Diets}

The treatments consisted of increasing tannic acid $(0 ; 1.3$; 2.6; 3.9 and 5.2\%) to replace corn bran in the diet, based on dry matter. The experimental diets were formulated and balanced to meet the requirements of lactating cows with an average production of $18 \mathrm{~kg} \mathrm{day}^{-1}$, according to the National Research Council (2007), offered in the form of roughage: concentrated in a fixed ratio of 64:36, respectively. Corn silage was used as roughage, and the concentrate was formulated from ground sorghum, ground corn, soybean meal, wheat bran, urea, and mineral mixture. The cows received $35 \mathrm{~kg}$ of corn silage daily as roughage, and $6.38 \mathrm{~kg}$ of concentrate composed of $3 \mathrm{~kg}$ ground sorghum, $1 \mathrm{~kg}$ ground corn, $1.5 \mathrm{~kg}$ soybean meal, $0.5 \mathrm{~kg}$ wheat bran, $0,2 \mathrm{~kg}$ urea, and $0.18 \mathrm{~kg}$ mineral mixture (Table 1).

The diet 0 (control) contained the sorghum cultivar BRS Ponta Negra without tannin. The other diets contained sorghum cultivar A9904, with tannin. To achieve increasing doses of tannin, PA acid (C76H52O46), tannic acid, acquired through the company Anidrol (laboratory products), was added, as it is a source of hydrolyzable tannin. Thus, in the experimental diets
Table 2. Percentage and bromatological composition of experimental diets.

\begin{tabular}{lccccc}
\hline \multirow{2}{*}{ Ingredient $(\% \mathrm{MN})$} & \multicolumn{5}{c}{ Tannic acid levels (\%) } \\
\cline { 2 - 6 } & 0.0 & 1.3 & 2.6 & 3.9 & 5.2 \\
\hline Corn silage $(\mathrm{kg})$ & 9.87 & 9.87 & 9.87 & 9.87 & 9.87 \\
Ground corn $(\mathrm{kg})$ & 0.87 & 0.87 & 0.87 & 0.87 & 0.87 \\
Soybean meal $(\mathrm{kg})$ & 1.32 & 1.32 & 1.32 & 1.32 & 1.32 \\
Wheat bran $(\mathrm{kg})$ & 0.44 & 0.44 & 0.44 & 0.44 & 0.44 \\
Urea $(\mathrm{kg})$ & 0.20 & 0.20 & 0.20 & 0.20 & 0.20 \\
Mineral mixture * $(\mathrm{kg})$ & 0.18 & 0.18 & 0.18 & 0.18 & 0.18 \\
Sorghum A9904 $(\mathrm{kg})$ & 0.00 & 2.58 & 2.58 & 2.58 & 2.58 \\
Sorghum Control $(\mathrm{kg})$ & 2.80 & 0.00 & 0.00 & 0.00 & 0.00 \\
Tannic acid (kg) & 0.00 & 0.015 & 0.0795 & 0.158 & 0.236 \\
Total & 15.68 & 15.48 & 15.54 & 15.69 & 15.70 \\
Nutritional composition & of the diet (bulk concentrate) $(\%)$ & \\
Dry matter & 36.85 & 37.30 & 37.30 & 37.30 & 37.30 \\
Crude protein & 15.55 & 15.46 & 15.46 & 15.46 & 15.46 \\
Ether extract & 1.99 & 2.08 & 2.08 & 2.08 & 2.08 \\
Neutral detergent fiber & 38.66 & 39.38 & 39.38 & 39.38 & 39.38 \\
Mineral matter & 5.48 & 5.67 & 5.67 & 5.67 & 5.67 \\
Non-fibrous & 33.68 & 33.24 & 33.24 & 33.24 & 33.24 \\
carbohydrates & & & & \\
Total carbohydrates & 68.92 & 69.27 & 69.27 & 69.27 & 69.27 \\
\hline
\end{tabular}

${ }^{*}$ Calcium carbonate; potassium chloride; sodium chloride (common salt); ventilated sulfur (sulfur flower); Dicalcium phosphate; magnesium oxide; copper amino carbon phosphoquelate; carbo amino chromium phosphoquelate; sulfur carbohydrate phosphoquelate; carbo amino iron phosphoquelate; carbo amino manganese phosphoquelate; carbo amino selenium phosphoquelate; carbo amino zinc phosphoquelate; Butylated toluene hydroxide (BHT); Calcium iodate; manganese monoxide; sodium selenite; cobalt sulfate; copper sulfate monohydrate; zinc sulfate; vitamin $\mathrm{A}$; vitamin $\mathrm{D} 3$; vitamin $\mathrm{E}$.

(Table 2), two condensed tannin sources were offered through the two sorghum cultivars and hydrolyzable through tannic acid.

The levels of tannic acid added to the diets were established based on the analysis of the amount of condensed tannin present in the sorghum, which, according to the methodology of HCLButanol (Hagerman \& Butler, 1981) carried out at the Bromatology Laboratory of UAG-UFRPE A9904 (cultivar A9904) was 2.55\% of total condensed tannin in DM. Control sorghum (cultivar BRS Ponta Negra) $0.92 \%$ of total condensed tannin in DM by Terril et al. (1992) carried out at EMBRAPA Sete Lagoas - MG.

Feeding was offered at will, twice a day, at 6:00 am and 1:30 pm, right after milking, with the concentrate separated 
from the roughage, to ensure the total consumption of tannic acid, which was added to the concentrate, in the pre-determined proportions of $1.5 ; 79.5 ; 157.5$ and $235.5 \mathrm{~g}$, in diets $2,3,4$ and 5, respectively. The leftover feed was collected in the morning and weighed to determine consumption; the water was available to all animals ad libitum.

\subsection{Sampling of milk}

The cows were milked twice a day mechanically, at 5:30 am and 1:00 pm. Before starting milking, the teats were cleaned with water and paper towels. The first jets were discarded in the black-bottomed mug to detect possible cases of clinical mastitis. After milking, the teats were cleaned with a commercial solution of iodine and glycerin. The record of individual milk productions was performed daily throughout the experimental period, by individual weighing $\left(\mathrm{kg} \mathrm{day}^{-1}\right)$, with a scale.

From the 11th to the 15th day of each experimental period, three collections of $200 \mathrm{~mL}$ of milk were made from each animal, the milk collected in the morning was stored in three sterile pet's bottles kept under refrigeration at $4{ }^{\circ} \mathrm{C}$, and the one collected in the afternoon was homogenized together with the chilled in the morning, being bottled and frozen immediately $\left(-18{ }^{\circ} \mathrm{C}\right)$ (Brasil, 2001). The samples were thawed at room temperature, forming a sample composed of the milk collected from each animal for three days during the collection period.

\subsection{Physical-chemical analysis of milk}

The chemical analysis of fat (\%), total solids (\%), proteins (\%), lactose $(\%)$, ash (\%), and casein $\left(\mathrm{g} 100^{-1}\right)$ were performed using an Analyzer of Master Complete Milk (AKSO', São Leopoldo, Rio Grande do Sul, Brazil), under specific technical conditions.

Milk production was corrected to $4 \%$ fat (MPC 4\%) according to the $\mathrm{NRC}^{15}$ equation: MPC $4 \%\left(\mathrm{~kg} \mathrm{day}^{-1}\right)=(0.4 \mathrm{x} \mathrm{MP})+[15 \mathrm{x}$ (\% fat $\mathrm{x}$ MP / 100)], where: MP corresponds to milk production $\left(\mathrm{kg} \mathrm{day}^{-1}\right)$ and $\%$ fat, the percentage of milk fat.

\subsection{Fatty acids}

The samples were homogenized with glass sticks, and $100 \mathrm{ml}$ aliquots of milk were removed and subjected to centrifugation for 5 minutes to separate the fat. From these samples, $2 \mathrm{~g}$ aliquots were obtained for the extraction, saponification, and esterification processes (Folch et al., 1957). We were added to the filtrate $4.4 \mathrm{ml}$ of the $1.5 \% \mathrm{NaCl}$ solution and centrifuged at $2400 \mathrm{rpm}$ for 20 minutes to separate the phases.

After centrifugation, the nonpolar phase, where fatty acids are in suspension, was transferred to tubes with a lid. These tubes were placed in a water bath at $50{ }^{\circ} \mathrm{C}$ and inflated with nitrogen gas until the solvent had evaporated entirely. After obtaining the lipid fraction, esterification was performed as recommended by Kramer et al. (1997). After that, $3.0 \mathrm{ml}$ of the $10 \%$ methanolic HCL solution was added and vortexed for 1 minute. Then the tubes were again taken to the water bath at $80^{\circ} \mathrm{C}$ for 10 minutes, removed and, after reaching room temperature, $1 \mathrm{ml}$ of hexane and $10 \mathrm{ml}$ of the $6 \%$ potassium carbonate solution were added, vortexed, and subsequently centrifuged at 1,500 rpm for 5 minutes to collect the supernatant.

The samples were injected in a gas chromatograph (model GC-2010 Plus Shimadzu ${ }^{\circ}$ ) provided with a fused silica capillary column (SP-2560; $100 \mathrm{~m}, 0,25 \mathrm{~mm}$ e 0,2 $\mu \mathrm{m}$ layer thickness, Supelco ${ }^{\circ}$. Stearic acid (C18:0) was used as an external standard and nonadecanoic acid (C19:0) as an internal standard to detect possible losses of fatty acids during the esterification process. The results of fatty acids were quantified by normalizing methyl esters' areas and expressed as a percentage of area.

From the fatty acid composition data, the total saturated fatty acids (SFA), monounsaturated (MUFA), polyunsaturated (PUFA) and the relationships between MUFA and SFA, PUFA and SFA, unsaturated fatty acids (UFA) and SFA were calculated, in addition to omega- 6 (n-6) and omega-3 (n-3) fatty acids. The nutritional quality of the lipid fraction was also evaluated using the Atherogenicity (AI) and Thrombogenicity (TI) index, as proposed by Ulbricth \& Southgate (Ulbricht \& Southgate, 1991).

$$
\begin{aligned}
& A I=[(C 12: 0+(4 * C 14: 0)+C 16: 0)] /(\Sigma M U F A+\Sigma n 6+\Sigma n 3) \\
& T I=(C 14: 0+C 16: 0+C 18: 0) / \\
& /\left[(0,5 * \Sigma M U F A)+(0,5 * \Sigma n 6)+(3 * \Sigma n 3)+\left(\sum n 3 / \Sigma n 6\right)\right]
\end{aligned}
$$

\subsection{Statistical analysis}

Data were subjected to variance analysis (ANOVA), and the averages were compared by Tukey test at $5 \%$ probability, through the PROC GLM and regression analysis was executed using the REG procedure on SAS software v 9.0 (Statistical Analysis System Institute, 2010).

\section{Results}

Dry matter intake, milk production, milk production corrected to $4 \%$ fat, fat, protein, ash, total solids, nongreasy solids, acidity, $\mathrm{pH}$, and stability were not influenced $(\mathrm{P}>0.05)$ by the addition of tannic acid to the diet of dairy cows (Table 3 ).

The DM intake was not influenced $(\mathrm{P}>0.05)$ by the inclusion of tannic acid in the diets, which means that the maximum dose of tannic acid used in this study (hydrolyzable tannin) plus the dose of condensed tannin from the sorghum offered ( $0.3210 \mathrm{~kg} / \mathrm{cow} /$ day $)$, did not cause a significant drop in palatability $(\mathrm{P}>0.05)$ to the point of affecting consumption by cows (Table 3 ).

Lactose was influenced $(\mathrm{P}<0.05)$ by including tannic acid in 'dairy cows' diet. There was an increase in concentration to the level of 2.6, at the next level, a decrease in concentration, and then at level 5.2, there was an increase.

Fatty acids were not influenced $(\mathrm{P}>0.05)$ by including tannic acid in ' dairy cows' diet. The presence of 24 fatty acids was identified in cow's milk: 15 saturated with short, medium, and long chains (C4 to $\mathrm{C} 20$ ); 5 medium and long-chain monounsaturated 
(C14 to C20) and 4 long-chain polyunsaturated (C18 to C20) (Table 4). The PUFA concentration did not change $(\mathrm{P}>0.05)$ due to the tannic acid levels in the cows' diets. However, the addition of tannic acid at the highest levels increased the concentrations of $(\alpha-)$ Linolenic, $(y)$ - Linolenic acids, Eicosadienoic).
The inclusion of tannic acid in the diet of dairy cows did not influence $(\mathrm{P}>0.05)$ the nutritional quality indexes of the lipid fraction of milk (Table 5), which reflects the absence of more significant effects of treatments on the profile of milk. The Fatty acids from milk fat are available in Table 4.

Table 3. Milk production and quality of cows supplemented with increasing levels of tannic acid.

\begin{tabular}{|c|c|c|c|c|c|c|c|}
\hline \multirow{2}{*}{ Variable } & \multicolumn{5}{|c|}{ Tannic acid levels (\%) } & \multicolumn{2}{|c|}{ P-value } \\
\hline & 0.0 & 1.3 & 2.6 & 3.9 & 5.2 & Linear & Quadratic \\
\hline Dry matter intake $\left(\mathrm{kg} \mathrm{day}^{-1}\right)$ & $14.75 \pm 1.10$ & $14.40 \pm 1.05$ & $14.92 \pm 1.12$ & $14.80 \pm 1.10$ & $14.08 \pm 1.03$ & 0.571 & 0.483 \\
\hline Milk production $\left(\mathrm{kg} \mathrm{day}^{-1}\right)$ & $15.71 \pm 1.22$ & $15.96 \pm 0.72$ & $15.80 \pm 1.01$ & $15.41 \pm 0.83$ & $14.74 \pm 1.82$ & 0.152 & 0.079 \\
\hline MPC 4\%, $\left(\mathrm{kg} \mathrm{day}^{-1}\right)$ & $14.01 \pm 1.01$ & $13.97 \pm 1.05$ & $14.62 \pm 1.25$ & $14.65 \pm 1.15$ & $14.12 \pm 1.01$ & 0.722 & 0.238 \\
\hline Fat (\%) & $3.28 \pm 0.50$ & $3.17 \pm 0.48$ & $3.50 \pm 0.38$ & $3.67 \pm 0.52$ & $3.72 \pm 0.59$ & 0.111 & 0.558 \\
\hline Protein (\%) & $3.45 \pm 0.08$ & $3.50 \pm 0.10$ & $3.27 \pm 0.21$ & $3.62 \pm 0.10$ & $3.28 \pm 0.20$ & 0.665 & 0.734 \\
\hline Lactose & $4.42 \pm 0.16 \mathrm{~b}$ & $4.50 \pm 0.11 \mathrm{ab}$ & $4.77 \pm 0.24 \mathrm{ab}$ & $4.47 \pm 0.12 \mathrm{ab}$ & $4.83 \pm 0.26 \mathrm{a}$ & 0.054 & 0.938 \\
\hline Ash (\%) & $0.54 \pm 0.02$ & $0.56 \pm 0.03$ & $0.60 \pm 0.02$ & $0.53 \pm 0.03$ & $0.54 \pm 0.02$ & 0.793 & 0.355 \\
\hline Total solids (\%) & $12.26 \pm 0.18$ & $12.68 \pm 0.12$ & $12.53 \pm 0.15$ & $12.76 \pm 0.20$ & $11.99 \pm 0.18$ & 0.648 & 0.113 \\
\hline Non-greasy solids (\%) & $8.98 \pm 0.26$ & $9.51 \pm 0.28$ & $8.75 \pm 0.19$ & $9.09 \pm 0.15$ & $8.27 \pm 0.26$ & 0.055 & 0.147 \\
\hline Acidity (\%) & $21.60 \pm 2.12$ & $19.80 \pm 1.15$ & $18.80 \pm 1.16$ & $18.80 \pm 1.13$ & $17.80 \pm 2.06$ & 0.086 & 0.359 \\
\hline $\mathrm{pH}$ & $6.61 \pm 0.06$ & $6.56 \pm 0.05$ & $6.60 \pm 0.06$ & $6.60 \pm 0.05$ & $6.62 \pm 0.07$ & 0.474 & 0.218 \\
\hline Stability & $84.94 \pm 2.12$ & $83.50 \pm 1.19$ & $85.10 \pm 1.05$ & $84.08 \pm 1.20$ & $84.90 \pm 1.18$ & 0.847 & 0.545 \\
\hline
\end{tabular}

Different letters on the line differ from each other by the Tukey test at the $5 \%$ level; milk production corrected for $4 \%$ fat = MPC $4 \%$

Table 4. Fatty acid profile of milk fat from cows supplemented with increasing levels of tannic acid.

\begin{tabular}{|c|c|c|c|c|c|c|c|}
\hline \multirow{2}{*}{ Variable } & \multicolumn{5}{|c|}{ Tannic acid levels (\%) } & \multicolumn{2}{|c|}{$P$-value } \\
\hline & 0.0 & 1.3 & 2.6 & 3.9 & 5.2 & Linear & Quadratic \\
\hline C4:0 & $3.06 \pm 2.09$ & $3.02 \pm 2.01$ & $3.09 \pm 2.16$ & $2.88 \pm 1.88$ & $2.89 \pm 1.88$ & 0.853 & 0.485 \\
\hline C6:0 & $7.85 \pm 2.89$ & $7.73 \pm 2.87$ & $7.59 \pm 2.74$ & $7.67 \pm 2.89$ & $7.58 \pm 2.75$ & 0.192 & 0.586 \\
\hline C8:0 & $5.95 \pm 1.52$ & $6.21 \pm 1.93$ & $5.91 \pm 1.58$ & $6.01 \pm 1.67$ & $6.17 \pm 1.82$ & 0.613 & 0.727 \\
\hline $\mathrm{C} 10: 0$ & $2.17 \pm 0.50$ & $1.93 \pm 0.96$ & $2.31 \pm \pm 0.45$ & $2.24 \pm 0.46$ & $2.19 \pm 0.42$ & 0.346 & 0.877 \\
\hline C11:0 & $0.15 \pm 0.09$ & $0.15 \pm 0.09$ & $0.18 \pm 0.02$ & $0.20 \pm 0.05$ & $0.13 \pm 0.11$ & 0.963 & 0.291 \\
\hline $\mathrm{C} 12: 0$ & $25.04 \pm 1.68$ & $27.45 \pm 2.32$ & $27.35 \pm 2.69$ & $26.43 \pm 2.43$ & $26.43 \pm 2.59$ & 0.852 & 0.348 \\
\hline $\mathrm{C} 13: 0$ & $4.10 \pm 0.51$ & $4.11 \pm 0.47$ & $4.19 \pm 0.47$ & $4.16 \pm 0.48$ & $4.09 \pm 0.54$ & 0.825 & 0.093 \\
\hline C14:0 & $29.98 \pm 2.89$ & $29.19 \pm 3.63$ & $29.66 \pm 3.12$ & $29.19 \pm 4.16$ & $28.90 \pm 3.65$ & 0.368 & 0.979 \\
\hline $\mathrm{C} 15: 0$ & $0.73 \pm 0.09$ & $0.71 \pm 0.09$ & $0.75 \pm 0.07$ & $0.74 \pm 0.09$ & $0.72 \pm 0.07$ & 0.819 & 0.449 \\
\hline $\mathrm{C} 16: 0$ & $127.30 \pm 11.12$ & $127.93 \pm 13.00$ & $126.17 \pm 11.29$ & $128.16 \pm 13.03$ & $127.68 \pm 14.43$ & 0.660 & 0.564 \\
\hline $\mathrm{C} 17: 0$ & $9.83 \pm 0.92$ & $9.98 \pm 0.89$ & $10.02 \pm 1.33$ & $10.27 \pm 1.21$ & $10.12 \pm 1.25$ & 0.288 & 0.677 \\
\hline C18:0 & $393.29 \pm 35.37$ & $392.18 \pm 38.14$ & $392.84 \pm 37.34$ & $392.88 \pm 36.29$ & $394.21 \pm 36.41$ & 0.460 & 0.299 \\
\hline C20:0 & $3.62 \pm 2.14$ & $4.25 \pm 0.52$ & $4.22 \pm 0.54$ & $4.15 \pm 0.48$ & $4.43 \pm 0.66$ & 0.275 & 0.651 \\
\hline $\mathrm{C} 21: 0$ & $24.58 \pm 5.88$ & $24.90 \pm 6.31$ & $23.65 \pm 6.23$ & $25.17 \pm 5.69$ & $25.21 \pm 6.33$ & 0.296 & 0.207 \\
\hline $\mathrm{C} 22: 0$ & $14.04 \pm 1.77$ & $14.33 \pm 1.75$ & $14.45 \pm 1.68$ & $14.81 \pm 1.77$ & $14.64 \pm 1.84$ & 0.240 & 0.496 \\
\hline$\Sigma$ SFA & $622.74 \pm 41.51$ & $622.78 \pm 50.14$ & $652.42 \pm 47.18$ & $655.00 \pm 41.44$ & $655.45 \pm 43.22$ & 0.798 & 0.887 \\
\hline C14:1 & $0.98 \pm 0.41$ & $0.88 \pm 0.64$ & $0.99 \pm 0.35$ & $0.97 \pm 0.38$ & $0.97 \pm 0.32$ & 0.712 & 0.738 \\
\hline $\mathrm{C} 15: 1 \mathrm{n}-5 \mathrm{c}$ & $1.50 \pm 0.29$ & $1.48 \pm 0.29$ & $1.48 \pm 0.30$ & $1.48 \pm 0.28$ & $1.49 \pm 0.28$ & 0.377 & 0.109 \\
\hline C16:1 n-7 & $14.70 \pm 3.02$ & $15.35 \pm 2.49$ & $14.05 \pm 3.05$ & $15.01 \pm 2.00$ & $14.78 \pm 2.46$ & 0.900 & 0.791 \\
\hline $\mathrm{C} 17: 1 \mathrm{n}-7 \mathrm{c}$ & $3.56 \pm 0.70$ & $3.27 \pm 0.82$ & $3.49 \pm 0.74$ & $3.27 \pm 0.78$ & $3.21 \pm 0.88$ & 0.185 & 0.962 \\
\hline $\mathrm{C} 18: 1 \mathrm{n}-9 \mathrm{c}$ & $16.60 \pm 1.42$ & $16.27 \pm 1.30$ & $17.20 \pm 1.59$ & $16.76 \pm 1.30$ & $16.15 \pm 0.70$ & 0.793 & 0.297 \\
\hline ¿MUFA & $37.64 \pm 4.00$ & $37.46 \pm 3.17$ & $37.64 \pm 4.52$ & $37.51 \pm 2.87$ & $36.61 \pm 2.82$ & 2.967 & 2.897 \\
\hline$C 18: 2 n-6 c$ & $7.71 \pm 2.27$ & $7.41 \pm 2.51$ & $7.43 \pm 2.55$ & $7.36 \pm 2.50$ & $7.45 \pm 2.41$ & 0.056 & 0.051 \\
\hline$C 18: 2 n-6 t$ & $4.82 \pm 3.18$ & $4.84 \pm 3.15$ & $4.64 \pm 3.32$ & $4.82 \pm 3.19$ & $4.73 \pm 3.24$ & 0.492 & 0.663 \\
\hline$C 18: 3 n-3$ & $69.37 \pm 19.33$ & $70.66 \pm 20.50$ & $68.55 \pm 19.59$ & $70.00 \pm 19.30$ & $69.98 \pm 20.31$ & 0.851 & 0.782 \\
\hline$C 18: 3 n-6$ & $2.75 \pm 1.12$ & $2.23 \pm 1.66$ & $2.66 \pm 1.16$ & $2.19 \pm 1.75$ & $2.79 \pm 1.12$ & 0.964 & 0.146 \\
\hline$\Sigma$ PUFA & $86.16 \pm 12.70$ & $86.11 \pm 13.51$ & $84.69 \pm 12.70$ & $84.38 \pm 13.58$ & $86.60 \pm 13.38$ & 2.363 & 1.642 \\
\hline
\end{tabular}

Different letters on the line differ from each other by the Tukey test at the $5 \%$ level; $\Sigma$ SFA $=$ sum of saturated fatty acids; $\Sigma$ MUFA $=$ sum of monounsaturated fatty acids; $\Sigma$ PUFA $=$ sum of polyunsaturated fatty acids. 


\section{Discussion}

Factors such as the composition of dietary carbohydrates, roughage: concentrate and nature of the lipid source, race, and lactation period resulted in changes, mainly in fat content and in the profile of milk fatty acids (Costa et al., 2009). The fat content of milk is following that required by IN 62 (Brasil, 2011), which establishes the minimum standard of $3.0 \%$ fat in raw milk.

The variation in the value of lactose was not expected, because according to the literature, this is the component of milk that suffers the least change due to the diet, having an essential role in osmotic regulation of milk (Fonseca \& Santos, 2000). Otherwise, the lactose production contributes to higher milk production butour results for the lactose content contradict this hypothesis. Benchaar et al. (2007) observed in cows at the beginning of lactation supplemented with a compound of essential oils with tannins (including thymol, eugenol, vanillin, guaiacol, and limonene) at a dose of $750 \mathrm{mg} / \mathrm{cow} /$ day, the lactose concentration in milk that was higher for the cows fed with essential oil compounds when compared to those that did not receive the supplement ( 4.78 vs. $4.58 \%$ ), suggesting, therefore, an effect on the concentration of rumen liquid propionate, the primary gluconeogenic substrate for glucose production in the liver that is used for the synthesis of lactose in the mammary gland (Berchielli et al., 2011).

Water consumption can be another answer to the increase in the lactose content. The adequate amount of water ingested is essential for the health and productivity of ruminants. However, some factors, such as annins' presence, can cause changes in water consumption (Kronberg \& Schauer, 2013). The highest water intake observed in the $5.2 \%$ treatment $(44.97 \mathrm{~L}$ ) probably occurred due to the astringent effects caused in the cows' mouth probably occurred due to the astringent effects caused the cows' mouth in concomitant interactions of tannins and salivary proteins. Probably when a higher level of tannic acid was offered in the cows' diet, drinking more water favoring the breakdown of tannic acid and a greater supply of glucose in the mammary gland for the synthesis of lactose.

According to Nudda et al. (2014), short and medium-chain fatty acids originate from the synthesis of de novo, acetate, and $\beta$-hydroxybutyrate, which result from ruminal fermentation. The main metabolic pathway for de novo synthesis involves two lipogenic enzymes: acetyl-CoA carboxylase and fatty acid synthetase. The first is responsible for the formation of malonylCoA from acetate, and the second catalyzes the condensation of malonyl-CoA with acetyl-CoA butyryl-CoA, produced from the metabolism of acetate and $\beta$-hydroxybutyrate, respectively (Chilliard et al., 2000). In in vitro experiments, Vasta et al. (2009) demonstrated the effect of tannin on ruminal biohydrogenation by inhibiting ruminal microorganisms' activity, favoring the accumulation of vaccenic acid and a reduction in stearic acid. However, in vivo experiments with tannins on their effect on ruminal biohydrogenation and modification CLA-rich milk composition are contradictory.

Toral et al. (2011) did not find any significant alteration in the profile of PUFA, mainly of the CLA (cis-9, trans-11) of the milk by the addition of tannin extract with sunflower oil in the bed of lactating sheep when compared to the control diet containing sunflower oil. Possibly, the dose used and the type of tannin, or both, may have been responsible for not changing the profile of fatty acids in milk.

Linoleic acids (C18: 2 n-6c) and $\alpha$ - Linolenic acids (C18: 3 n-3) are not biosynthesized in animals, including man, is considered essential, and therefore, must be supplied via diet. It is important to note that Linoleic acid and $\alpha$ - Linolenic acid are the precursors of PUFA $\omega-6$ and $\omega-3$ of longer chains. Second Santos \& Borto-Lozo (2008) fatty acids of classes $\omega-3$ and $\omega-6$ act in several functions of the body and can contribute to the treatment or prevention of cancer, arthritis, depression, Alzheimer's disease, blood pressure control, heart rate, vascular dilation, blood clotting, and immune response.

The atherogenicity and thrombogenicity index indicate the potential to stimulate platelet aggregation, once lower AI and TI values, greater the amount of anti-atherogenic fatty acids present in the fat and, consequently, more significant is the potential for preventing the onset of coronary heart disease (Turan et al., 2007). According to Bentes et al. (2009), there are no recommended values for AI and TI in dairy products, and it is considered that the lower the values of these indexes, the better the fatty acid profile for human health. Bobe et al. (2004) mention that dairy products generally have AI around 2 , being following the general average (2.26) found in this research for this index.

Table 5. Nutritional quality indices of the lipid fraction of milk from cows supplemented with increasing levels of tannic acid.

\begin{tabular}{lccccccc}
\hline \multirow{2}{*}{\multicolumn{1}{c}{ Variable }} & \multicolumn{4}{c}{ Tabbic acid levels (\%) } & \multicolumn{2}{c}{$P$-value } \\
\cline { 2 - 5 } \cline { 5 - 6 } & 0.0 & 1.3 & 2.6 & 3.9 & 5.2 & Linear & Quadratic \\
\hline Omega-6, g kg-1 $^{-1}$ & $15.28 \pm 6.06$ & $14.49 \pm 5.93$ & $14.74 \pm 6.56$ & $14.38 \pm 6.06$ & $14.98 \pm 6.27$ & 0.482 & 0.092 \\
Omega-3, g kg $^{-1}$ & $69.37 \pm 19.33$ & $70.66 \pm 20.50$ & $68.55 \pm 19.57$ & $69.99 \pm 19.30$ & $69.98 \pm 20.31$ & 0.851 & 0.782 \\
Monounsaturated: Saturated (MUFA/SFA) & $0.05 \pm 0.004$ & $0.05 \pm 0.003$ & $0.05 \pm 0.004$ & $0.05 \pm 0.002$ & $0.05 \pm 0.004$ & 0.311 & 0.479 \\
Polyunsaturated: Saturated (PUFA/SFA) & $0.13 \pm 0.02$ & $0.13 \pm 0.02$ & $0.12 \pm 0.01$ & $0.12 \pm 0.02$ & $0.13 \pm 0.02$ & 0.436 & 0.213 \\
Unsaturated: Saturated (UFA/SFA) & $0.18 \pm 0.01$ & $0.19 \pm 0.01$ & $0.18 \pm 0.01$ & $0.18 \pm 0.01$ & $0.18 \pm 0.02$ & 0.229 & 0.596 \\
Atherogenicity index & $2.26 \pm 0.01$ & $2.25 \pm 0.02$ & $2.28 \pm 002$ & $2.26 \pm 0.01$ & $2.25 \pm 0.03$ & 0.864 & 0.800 \\
Thrombogenicity index & $2.39 \pm 0.04$ & $2.36 \pm 0.05$ & $2.42 \pm 0.04$ & $2.37 \pm 0.03$ & $2.39 \pm 0.03$ & 0.931 & 0.996 \\
\hline
\end{tabular}

Different letters on the line differ from each other by the Tukey test at the $5 \%$ level. 


\section{Conclusion}

The inclusion of tannic acid up to $5.2 \%$ in dairy cows' diet did not affect the consumption of dry matter, the quality and production of milk, either nor interfered with fatty acids. However, it promoted an increase in lactose content. Atherogenicity and thrombogenicity index reveal the potential for preventing the onset of coronary heart disease.

\section{References}

Addis, M., Pinna, G., Molle, G., Fiori, M., Spada, S., Decandia, M., Scintu, M. F., Piredda, G., \& Pirisi, A. (2006). The inclusion of a daisy plant (Chrysanthemum coronarium) in dairy sheep diet: 2. Effect on the volatile fraction of milk and cheese. Livestock Science, 101(1-3), 68-80. http://dx.doi.org/10.1016/j. livprodsci.2005.09.009.

Agiral, S., Budak, S. O., Tamer, S. I., Ozer, B., \& Yazihan, N. (2020). Invitro digestion and absorption efficiency of homogenised milk lipids. International Journal of Dairy Technology, 74(1), 52-62. http:// dx.doi.org/10.1111/1471-0307.12723.

Apás, A. L., Arena, M. E., Colombo, S., \& González, S. N. (2015). Probiotic administration modifies the milk fatty acid profile, intestinal morphology, and intestinal fatty acid profile of goats. Journal of Dairy Science, 98(1), 47-54. http://dx.doi.org/10.3168/ jds.2013-7805. PMid:25465559.

Benchaar, C., Petit, H. V., Berthiaume, R., Ouellet, D. R., Chiquette, J., \& Chouinard, P. Y. (2007). Effects of essential oils on digestion, ruminal fermentation, rumen microbial populations, milk production, and milk composition in dairy cows fed alfalfa silage or corn silage. Journal of Dairy Science, 90(2), 886897. http://dx.doi.org/10.3168/jds.S0022-0302(07)71572-2. PMid:17235165.

Bentes, A. S., Souza, H. A. L., Mendonça, X. M. F. D., \& Simões, M. G. (2009). Caracterização física e química e perfil lipídico de três espécies de peixes amazônicos. Revista Brasileira de Tecnologia Agroindustrial, 3(2), 97-108. http://dx.doi.org/10.3895/S1981-36862009000200011.

Berchielli, T. T., Pires, A. V., \& Oliveira, S. G. (2011). Nutrição de ruminantes. 2. ed. Jaboticaba, SP: Universidade Estadual Paulista.

Bobe, G., Zimmerman, S., Hammond, E.G., Gene Freeman, A.E., Lindberg, G., \& Beitz, D. (2004). Texture of butters made from milks differing in indices of atherogenicity (Animal Industry Report AS 650. Iowa: Iowa State University.

Brasil. (2011, Dezembro 30). Regulamento técnico de produção, identidade e qualidade do leite tipo A, leite cru refrigerado, leite pasteurizado, leite cru refrigerado e seu transporte a granel (Instrução Normativa $n^{\circ}$ 62, de 29 de dezembro de 2011). Diário Oficial [da] República Federativa do Brasil, seção 1.

Brasil. Ministerio da Agricultura. Secretaria Nacional de Agricultura. (2001). Regulamento Ténico de Produção, Identidade e Qualidade do Leite de Cabra (Instrução Normativa no 37,8 de novembro de 2000). Diário Oficial da União, seção 1.

Carreño, D., Hervás, G., Toral, P. G., Belenguer, A., \& Frutos, P. (2015). Ability of different types and doses of tannin extracts to modulate in vitro ruminal biohydrogenation in sheep. Animal Feed Science and Technology, 202, 42-51. http://dx.doi.org/10.1016/j. anifeedsci.2015.02.003.

Chilliard, Y., Ferlay, A., Mansbridge, R. M., \& Doreau, M. (2000). Ruminant milk fat plasticity: nutritional control of saturated, polyunsaturated, trans and conjugated fatty acids. Annales de Zootechnie, 49(3), 81205. http://dx.doi.org/10.1051/animres:2000117.
Costa, R. G., Queiroga, R. C. R., \& Pereira, R. A. G. (2009). Influence of feed on the production on quality of goat milk. Revista Brasileira de Zootecnia, 38, 307-321. http://dx.doi.org/10.1590/S151635982009001300031 .

Delacroix-Buchet, A., \& Lamberet, G. (2000). Sensorial properties and typicity of goat dairy products. Tours/France: International Association of Goat, 2, 559-563.

Abd El-Salam, M. H., \& El-Shibiny, S. (2020). Milk fat globule membrane: An overview with particular emphasis on its nutritional and health benefits. International Journal of Dairy Technology, 63(4), 639-655. http://dx.doi.org/10.1111/1471-0307.12730.

Folch, J., Lees, M., \& Stanley, G. H. S. (1957). A simple method for the isolation and purification of total lipids from animal tissues. The Journal of Biological Chemistry, 226(1), 497-509. http://dx.doi. org/10.1016/S0021-9258(18)64849-5. PMid:13428781.

Fonseca, L. F. L., \& Santos, M. V. (2000). Qualidade do leite e controle da mastite. São Paulo, Lemos Editorial.

Goel, G., Puniya, A. K., Aguilar, C. N., \& Singh, K. (2005). Interaction of Gut Microflora with tannins in feed. Naturwissenschafte. Dairy Microbiology Division, 92, 497-503. PMid:16193308.

Hagerman, A. E., \& Butler, L. G. (1981). The specificity of proanthocyanidinprotein interactions. The Journal of Biological Chemistry, 256(9), 4494-4497. http://dx.doi.org/10.1016/S0021-9258(19)69462-7. PMid:7217094.

Kramer, J. K., Fellner, V., Dugan, M. E., Sauer, F. D., Mossoba, A. M. M., \& Yurawecz, M. P. (1997). Evaluating acid and base catalysts in the methylation of milk and rumen and rumen fatty acids with special emphasis on conjugated dienes and total trans fatty acids. Lipid, 32(11), 1219-1228. http://dx.doi.org/10.1007/s11745-9970156-3. PMid:9397408.

Kronberg, S. L., \& Schauer, C. S. (2013). Cattle and sheep develop preference for drinking water containing grape seed tannin. Animal, 7(10), 1714-1720. http://dx.doi.org/10.1017/S1751731113001262. PMid:23880297.

Lopes, L. L., Peluzio, M. C. G., \& Hermsdorff, H. H. M. (2016). Monounsaturated fatty acid intake and lipid metabolism. Jornal Vascular Brasileiro, 15, 52-60. http://dx.doi.org/10.1590/16775449.008515.

Lopes, M. A., Santos, G., Resende, M. C., Carvalho, F. M., \& Cardoso, M. G. (2011). Estudo da rentabilidade de sistemas de produção de leite no município de Nazareno, MG. Ciência Animal Brasileira, 12(1), 58-69. http://dx.doi.org/10.5216/cab.v12i1.7725.

Madruga, M. S., Bezerra, T. K. A., Guerra, J. C. D., Batista, A. S. M., Silva, A. M. A., \& Fernandes, R. P. P. (2020). The effect of feed restriction on the fat profile of Santa Inês lamb meat. Acta Scientiarum, 42, e4905.

Monteiro, J. M., Albuquerque, U. P., Araújo, E. L., \& Amorim, E. L. C. (2005). Taninos: uma abordagem da química à ecologia. Quimica Nova, 28(5), 892-896. http://dx.doi.org/10.1590/S0100-40422005000500029.

National Research Council - NRC. (2007). Nutrient requirements of the dairy cattle (7th ed.). Washington, DC: National Academy Press.

Nudda, A., Battacone, G., Boaventura Neto, O., Cannas, A., Fracesconi, A. H. D., Atizori, A. S., \& Pulina, G. (2014). Feeding strategies to design the fatty acid profile of sheep milk and cheese. Revista Brasileira de Zootecnia, 43(8), 445-456. http://dx.doi.org/10.1590/ S1516-35982014000800008.

Palmquist, D. L. (2010). Great discoveries of milk for a healthy diet and a helsthy life. Revista Brasileira de Zootecnia, 39(Suppl. Spe), 465-477. http://dx.doi.org/10.1590/S1516-35982010001300051. 
Ruiz, J. P. A., Alonzo, M. W., \& Pertiñez, M. D. (2016). Conjugated linoleic acid of dairy foods is affected by cow's feeding system and processing of milk. Scientia Agrícola, 73(2), 103-108. http://dx.doi. org/10.1590/0103-9016-2015-0051.

Santos, L. E. S., \& Borto-Lozo, E. A. F. Q. (2008). Ingestão de ômega 3: considerações sobre potenciais benefícios no metabolismo lipídico. Ciências Exatas e da Terra. Agrárias e Engenharias, 14, 161-170.

Statistical Analysis System Institute - SAS. (2010). Institute SAS/STAT software. CD-ROOM. Iowa City: SAS.

Terril, T. H., Rowan, A. M., Douglas, G. B., \& Barry, T. N. (1992). Determination of extractable and bound condensed tannin concentration in forage plants, protein concentrate meals and cereal grains. Journal of the Science of Food and Agriculture, 58(3), 321-329. http://dx.doi.org/10.1002/jsfa.2740580306.

Toral, P. G., Hervás, G., Bichi, E., Belenguer, Á., \& Frutos, P. (2011). Tannins as feed additives to modulate ruminal biohydrogenation: Effects on animal performance, milk fatty acid composition and ruminal fermentation in dairy ewes fed a diet containing sunflower oil. Animal Feed Science and Technology, 164(3-4), 199-206. http:// dx.doi.org/10.1016/j.anifeedsci.2011.01.011.
Turan, H., Sonmez, G., \& Kaya, Y. (2007). Fatty acid profile and proximate composition of the thornback ray (Raja clavata, L. 1758) from the Sinop coast in the Black Sea. Journal Fisheries Science, 1(2), 97-103. http://dx.doi.org/10.3153/jfscom.2007012.

Ulbricht, T. L. V., \& Southgate, D. A. T. (1991). Coronary heart disease: Seven dietary factors. Lancet, 338(8773), 985-992. http://dx.doi. org/10.1016/0140-6736(91)91846-M. PMid:1681350.

Urbach, G. (2006). The flavour of milk and dairy products: II. Cheese: contribution of volatile compounds. International Journal of Dairy Technology, 50(3), 79-89. http://dx.doi.org/10.1111/j.1471-0307.1997. tb01743.x.

Vargas-Bello-Perez, E., Cancino-Padillo, N., Geldsetzer-mendoza, C., Morales, M. S., Leskinen, H., Garnsworthy, P. C., Loor, J. J., \& Romero, J. (2020). Effects of dietary polyunsaturated fatty acid sources on expression of lipid related genes in bovine milk somatic cells. Scientific Reports, 10(1), 14850. http://dx.doi.org/10.1038/s41598020-71930-x. PMid:32908177.

Vasta, V., Makkar, H. P., Mele, M., \& Priolo, A. (2009). Ruminal biohydrogenation as affected by tannins in vitro. British Journal of Nutrition, 102(1), 82-92. http://dx.doi.org/10.1017/S0007114508137898. PMid:19063768. 